\title{
THE OLDEST TENEBRIONIDAE (COLEOPTERA) \\ OF THE SUBFAMILY DIAPERINAE AND \\ THE TRIBE SCAPHIDEMINI \\ FROM THE PALEOCENE OF MENAT (FRANCE)
}

\author{
Maxim V. Nabozhenko ${ }^{1,2}$ and Alexander G. Kirejtshuk ${ }^{3}$ \\ ${ }^{1}$ Precaspian Institute of Biological Resources of the Daghestan Federal Research Centre of the \\ Russian Academy of Sciences, and \\ ${ }^{2}$ Dagestan State University, M. Gadzhiev str. 45, Makhachkala 367000, Russia \\ E-mail: nalassus@mail.ru, https://orcid.org/0000-0001-7914-79421 \\ ${ }^{3}$ Zoological Institute of the Russian Academy of Sciences \\ Universitetskaya emb., 1, St Petersbug 199034, Russia \\ E-mail: kirejtshuk@gmail.com, https://orcid.org/0000-0002-8826-02582
}

The oldest tenebrionid beetle Palaeobasanus neli gen. et sp. n. of the tribe Scaphidemini (subfamily Diaperinae) is described from the Paleocene of Menat (Thanetian) in France. The new extinct genus shows a distinct complex of characters of the tribe Scaphidemini, such as modified procoxal cavities, modified prosternal "cowling" and mesocoxal cavities partly closed by mesepimera. Palaeobasanus gen. $n$. differs from the extant Scaphidemini in the narrowly separated coxae, structure of prosternal process, which is moderately narrow at middle but strongly widened at apex and rounded (not truncate), abdominal intercoxal process, antennomeres $4-7$ clearly covered by simple trichoid sensilla but without round sensory complexes as in recent Scaphidemini and Diaperini. All these mentioned characters seem to be symplesiomorphies within the tenebrionoid lineage, including oldest Mesozoic 'tenebrionoid' darkling beetles. It is thought that Palaeobasanus gen. n. could be a basal group within Scaphidemini, closely related to Diaperini, which probably existed at least in the border of the Mesozoic and Cenozoic.

Key words: diversification of Diaperini and Scaphidemini, new species and genus, fossil tenebrionids, Tenebrionidae.

\section{INTRODUCTION}

Fossil Tenebrionidae were recently intensively investigated; however, many tenebrionids, superficially described during 19th and partly 20th centuries, need reexamination and revision. Here, we consider only the taxa undoubtedly belonging to the family Tenebrionidae. The oldest taxa of the family are known from the middle/late Jurassic of Karatau, Kazakhstan (Alleculinae Laporte, 1840: Jurallecula grossa Medvedev, 1969) (Medvedev 1969) and the early Cretaceous of Yixian Formation, China (Alleculinae: Platycteniopus diversoculatus Chang, Nabozhenko, $\mathrm{Pu}, \mathrm{Xu}$, Jia et $\mathrm{Li}, 2016$ and Calcarocistela kirejtshuki Nabozhenko in Nabozhenko, Chang, Pu, Xu, Jia et Li, 2015; Tenebrioninae: Alphitopsis initialis Kirejtshuk, Nabozhenko et Nel, 2011) (Kirejtshuk 
et al. 2012, Nabozhenko et al. 2015, Chang et al. 2016). Most Tenebrionidae were described and partly obtained from Paleogene deposits: the Paleocene of Menat (Nabozhenкo \& Kirejtshuк 2014, 2017), earliest Eocene Oise amber (Kirejtshuk et al. 2010), Eocene Baltic amber (Kirejtshuk et al. 2008, Alekseev \& Nabozhenko 2015, 2017, Nabozhenko et al. 2016a, b, Soldati \& Nabozhenкo 2017, Nabozhenko \& Chigray 2018, Nabozhenko et al. 2019a, b, Telnov et al. 2019), and late Eocene of Florissant Formation, Colorado (Wіскнам 1912, 1913).

The majority of fossil darkling beetles belongs to forest groups in tenebrioid and lagrioid lineages apparently adapted to humid environments. The pimeloid arid-adapted tenebrionids (at least the subfamily Pimeliinae Latreille, 1802) are scarce in the fossil record due to taphonomic reasons (SoLdati \& Nabozhenko 2017, Nabozhenko \& Kirejtshuk 2017). The tenebrioid lineage is represented by the subfamilies Tenebrioninae, Alleculinae, Diaperinae Latreille, 1802 and Stenochiinae Kirby, 1837 (Kirejtshuk et al. 2008). The first two mentioned groups have the greatest diversity in the fossil record. Diaperinae is represented by ten extinct species from eight extant genera. The oldest one is Ceropria messelense Hörnschemeyer, 1994 (Diaperini), described from the Messel paleolake, Germany (middle Eocene, 48.6-40.4 Ma) (HöRNschemeyer 1994). Other Paleogene species are known from the middle-late Eocene (37.2-33.9 Ma): Pentaphyllus cioides Kirejtshuk, Merkl et Kernegger, 2008 (Diaperini) from the Baltic amber (KIREJTSHUK et al. 2008) and two species of Platydema Laporte et Brullé, 1831 (Diaperini) from the late Eocene of Florissant (Wiскнам 1912, 1913). The Neogene taxa (early Miocene) from tribes Diaperini (subtribes Diaperina and Adelina Dejean, 1835) and Hypophlaeini were predominantly described from the Dominican amber (Kaszab \& SchAwaller 1984, Doyen \& Poinar 1994, Vitali 2007, 2008).

Here, a new extinct diaperine genus and species of the small tribe Scaphidemini from the Paleocene of Menat, France, is described. This group also includes four extant genera, distributed mainly in the Old World (Palaearctic, Indo-Malayan and Australian regions) (Doyen et al. 1990). Only one species is known in the New World (Bousquet et al. 2018).

\section{MATERIAL AND METHODS}

The holotype examined is deposited in the Menat Town Museum, Menat, Puy-deDôme, France (further MNT). It was studied using a stereomicroscope Olympus SCX9 in Muséum national d'Histoire naturelle, Paris (further MNHN) with different modes of light and color filters. The specimen was also examined with a Tescan Vega LSU scanning electron microscope in the Laboratory of Minéralogy and Cosmochemistry, MNHN. MNHN to test the characters not clearly visible in the usual optic stereomicroscope (punctation, outlines of legs, pronotum, pterothorax etc.) with the Low Vacuum Secondary Electron TESCAN Detector (LVSTD). 


\section{GEOLOGICAL SETTING AND LOCALITY}

Geological setting and stratigraphy, depositional environment as well as maps of Paleocene volcano-sedimentary maar are reviewed and summarized in many works (Piton 1940, Nel \& Auvray 2006, Wappler et al. 2009, etc.). The Menat Pit fossil site is located in France, Department of Puy-de-Dôme (near Gannat) $\left(46^{\circ} 06^{\prime} \mathrm{N}, 02^{\circ} 54^{\prime} \mathrm{E}\right)$. The age of the site, according to pollen, paleomammalian stratigraphic and radiometric K/Ar analyses was estimated as $59 \mathrm{Ma}$ (Kedves \& Russel 1982, NeL 2008). The estimation based on macroflora postulated its age within 60-61 Ma (WAPPLER et al. 2009).

Paleobiotic circumstances of Menat were briefly reviewed by NABOzHENко and Kirejtshuк (2017). In addition, the diversity of beetles and birds from this deposit was discussed in further publications (Legalov et al. 2017, 2019, Kirejtshuk \& Nel 2018, Mayr et al. 2019, etc.).

\section{Palaeobasanus gen. n.}

Family Tenebrionidae Latreille, 1802

Subfamily Diaperinae Latreille, 1802

Tribe Scaphidemini Reitter, 1922

Type species: Palaeobasanus neli sp. $\mathrm{n}$.

Etymology. The name of the new genus is formed from the Greek "palaeo" ( $\pi \alpha \lambda \alpha$ tó - old, ancient) and generic name "Basanus". Gender masculine.

Description. Body oval and medium-sized (body length nearly $7.5 \mathrm{~mm}$ ). Mouth parts of tenebrioid type, with open basal parts (cardo and stipes); mentum transverse, trapezoidal; gula with rounded margins, not reaching submentum. Antennomeres 5-7 elongate; apical antennomeres (beginning from antennomere 8) forming an unclear club. Pronotum trapezoidal, widest at base; anterior margin twice narrower than base; each side of pronotum with deep furrow along edge. Prosternum moderate before coxae, about twice as long as postcoxal bridge, with cleft lateral margin of the procoxal cavities. Prosternal process narrow between coxae and strongly widened behind coxae. Mesocoxal cavities partly closed by mesepimera and mesotrochantin. Elytra with eight visible distinct striae, each with one row of dense and distinct punctures (elytra with indistinct lateral striae in extant scaphidemins) and scutellary striola; interstriae convex; epipleura narrow, terminating before apex. Abdomen with distinct intersegmental membranes between ventrites 3-5; abdominal intercoxal process widely rounded. Legs (at least hind ones) moderately long, with tibiae subequal in length with femora. Metatarsomere 1 long, but slightly shorter than metatarsomere 4 .

Comparison. Palaeobasanus gen $\mathrm{n}$. clearly belongs to the tribe Scaphidemini due to the following characters: tarsi heteromerous; base of scape concealed by gena; tenebrioid mouthparts (open cardo and stipes); cleft lateral margin of 
procoxal cavities; present scutellary striola; mesocoxal cavities partly closed by mesepimeron and trochantine; tenebrionoid hinging of abdomen with visible intersegmental membranes (defensive glands present).

The new genus is externally similar to extant species of the genus Basanus Lacordaire, 1859 but clearly differs from all Scaphidemini in the structure
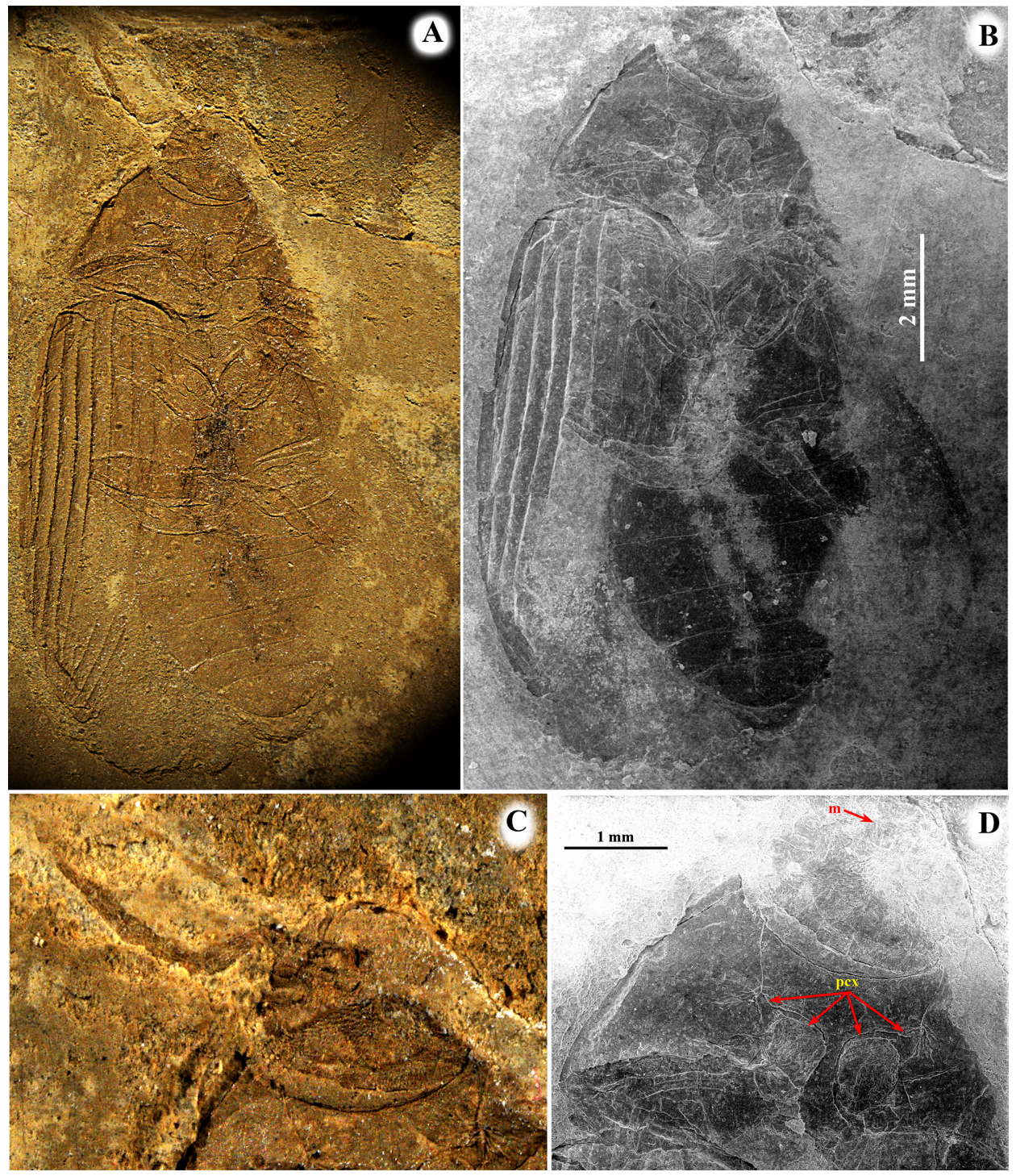

Fig. 1. Palaeobasanus neli gen. et sp. n. holotype, Paleocene of Menat (France) imprint: A = imprint, general view, optic microscope, $\mathrm{B}=$ the same, SEM, C = head, optic microscope, $\mathrm{D}=$ prosternum and head, $\mathrm{SEM}, \mathrm{m}=$ mentum, $\mathrm{pcx}=$ procoxae 
of the abdominal intercoxal process, which is widely rounded unlike widely truncate. The genus additionally differs from

- Scaphidema Redtenbacher, 1848 and Spiloscapha Bates, 1873 in the antennomeres 4-7 not elongate (gradually or abruptly widening distally) and the large body (in extant genera, the body length is within 3.5-5 mm)

- Basanus Lacordaire, 1859 in the narrower antennomeres and the metatarsomere 1 slightly shorter than metatarsomere 4 (in Basanus, the metatarsomere 1 is clearly longer than metatarsomere 4 ).

- Laoscapha Schawaller, 2016 in the antennomeres 4-7 not elongate and the metatarsomere 1 clearly longer than metatarsomere 2 .

\section{Palaeobasanus neli sp. $\mathrm{n}$.}

(Figs 1-2)

Type material: holotype MNT 063415 (sex unknown)

Description. Body length about $7.5 \mathrm{~mm}$. Head about half as wide as pronotum; mentum with longitudinal median elevation (Fig 1D); Head underside with dense and coarse subcircular punctures around throat emargination; other ventral sclerites with undulate

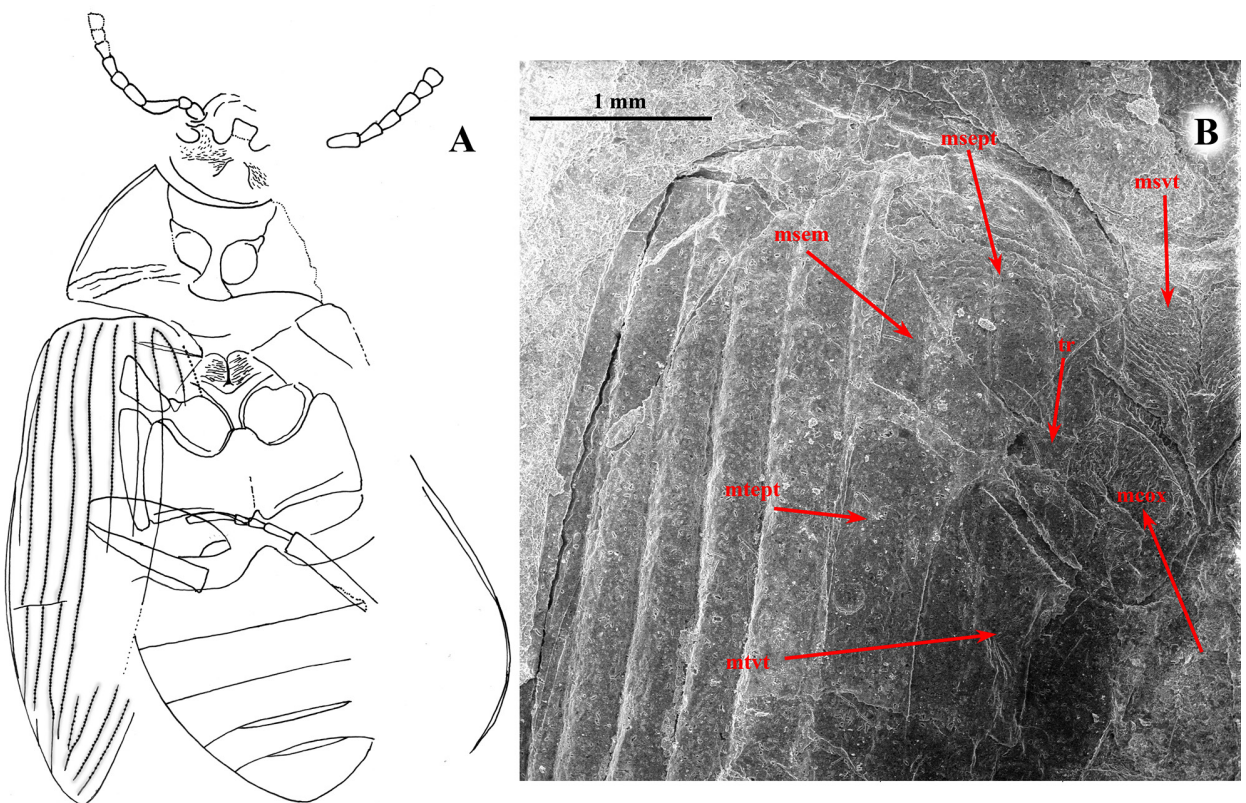

Fig. 2. Palaeobasanus neli gen. et sp. n. holotype, Paleocene of Menat (France), details of the structure: $\mathrm{A}=$ reconstruction, $\mathrm{B}=$ right half of pterothorax, $\mathrm{msvt}=$ mesoventrite, msept $=$ mesepisternum, $\mathrm{msem}=$ mesepimeron, $\mathrm{tr}=$ trochantine, $\mathrm{mtept}=$ metaepisternum, $\mathrm{mtvt}=$ metaventrite, $\mathrm{mcox}=$ mesocoxa 
transverse wrinkle-like foveae (Fig. 1D); gula short, with weakly rounded margins. Antennomeres 4-7 elongate, with dense simple trichoid sensillae (Fig. 1C), without sensory complexes; apical antennomeres (beginning from antennomere 8) subquadrate and short.

Pronotum transverse (Figs 1A, B, D; 2A), nearly 3.5 times as wide as long, widest at base; lateral margins and base evenly weakly arcuate; anterior margin shallowly emarginated; lateral margins strongly beaded (Fig. 1B, D); anterior angles subacute, weakly projected; posterior angles subacute but rounded at tip.

Elytra at base little wider than base of pronotum, with eight striae and scutellary striola; humeri rounded, not projected; striae deep, bearing a row of circular punctures at bottom (Figs 1A, 2A). Mesoventrite with median elevation and transverse wrinkles, strongly depressed before mesocoxae; mesocoxae transversely suboval; metaventrite transverse (2.6 times as wide as long, with median impressed furrow in basal part and groove along metacoxal cavities; intercoxal process of metaventrite rounded and beaded.

Legs moderately long; femora not strongly protruded beyond body lateral edges; tibiae straight; metatarsi with long metatarsomeres 1 and 4 ; metatarsomere 4 the longest (longer than metatarsomeres 2 and 3 combined).

Etymology. The species is named in honor of Prof. André Nel (MNHN), the famous paleoentomologist, who made a great contribution to the study of the paleofauna of Menat.

Comparative diagnosis is the same as for the genus Palaeobasanus gen. $\mathrm{n}$.

\section{DISCUSSION}

Doyen et al. (1990) resurrected the tribe Scaphidemini in a new sense from Diaperini, based on the following imaginal synapomorphies: (1) structures of female genital tubes, (2) tentorium, (3) prosternal process, (4) modified procoxal cowling. This tribe includes five genera: Scaphidema, Basanus, Spiloscapha, Laoscapha and Pseudoscaphidema Pic, 1926. According to the original description, this last genus, monotypic from Kamchatka, distinctly belongs to the genus Phaleromella Reitter, 1916 (Diaperinae Phaleriini Blanchard, 1845), as well with only one species - P. subhumeralis (Marseul, 1876) - from Kamchatka. This should be confirmed only after study of the type material. The range of Scaphidemini occupies Holarctic, Indo-Malayan and Australian regions, but the greatest diversity of the tribe is observed in Palaearctic Eastern Asia and Indo-Malayan Region (Schawaller 1995, 1997, 2003, 2004, 2006, 2008, 2011, 2012, 2016, Masumoto \& Merkl 2003, Ando \& Schawaller 2006, Schawaller \& Ando 2006, Grimm 2010). Only one species of Spiloscapha reaches Australia (Matthews \& Bouchard 2008) and one Scaphidema occurs in North America (Schawaller 2003).

Doyen et al. (1990, note 27) indicated the phylogenetic position as "the less derived sister clade to the Nilionini-Leiochrini". The last two tribes were combined by Watт (1974). Among the listed characters, the third and fourth ones are clearly visible on the imprint of Palaeobasanus gen. n. Such structures 
of the procoxal cavities, as the anterior and posterior lobes of the cowling that meet at an acute angle leaving the coxa exposed along about half its length, are typical for Scaphidemini, Nilionini Oken, 1843 and Leiochrini Lewis, 1894, and distinctly distinguish these groups from the other Tenebrionidae. Within these tribes, the very wide prosternal process, as wide as diameter of the procoxa, is peculiar for Scaphidemini.

MatTHews and Bouchard (2008) stated that Scaphidemini are difficultly separable from Diaperini based on external characters, but they mentioned differences, as the cleft lateral margins of the procoxal cavities, the somewhat more widely separated coxae and the wide truncate intercoxal process of abdomen.

Palaeobasanus neli sp. n. shows a distinct set of characters of Scaphidemini, such as the modified procoxal cavities, the modified prosternal cowling and the mesocoxal cavities partly closed by mesepimera (Fig. 2B) (unlike Leiochrini, which show coxae closed by meso- and metaventrites). Similar type of cavities and 'open' mesocoxal cavities are also typical for Nilionini, but this tribe, as well Leiochrini, shows hemispherical body and epipleura notched at the level of metacoxae, which is unique within the Tenebrionidae (Doyen et al. 1990).

Palaeobasanus gen. $n$. differs from the extant Scaphidemini in the narrowly separated coxae, structure of the prosternal process, which is moderately narrow at middle but strongly widened at apex, and rounded (not truncate) abdominal intercoxal process. All these characters seem to be symplesiomorphies within the tenebrionoid lineage, including the oldest Mesosoic tenebrionoid darkling beetles as Alleculinae and Tenebrioninae (Alphitobiini Reitter, 1917). The prosternal process strongly widened at apex is probably a 'transitional' character between the typical 'tenebrionoid' and the 'scaphidemin' types. The abdominal intercoxal process of Palaeobasanus gen. n. also shows 'transitional' features between the widely truncate type of the extant Scaphidemini and the triangular type of Diaperini and most of other darkling beetles of the tenebrioid lineage. In addition, the antennomeres 4-7 of Palaeobasanus gen. $\mathrm{n}$. are clearly covered by simple trichoid sensilla, without round sensory complexes, as in the recent Scaphidemini and Diaperini. This is also typical for most extant darkling beetles of the tenebrionoid lineage (Medvedev 1977). These characters suggest that Palaeobasanus gen. n. apparently is a 'basal' group within Scaphidemini, closely related to Diaperini and evolved possibly at the border of Mesozoic and Cenozoic.

Acknowledgements - The authors greatly appreciate in first turn André Nel (MNHN) who made this study possible. Sylvain Pont (Minéralogie et Cosmochimie, MNHN) essentially assisted to study the holotype by electronic microscopy. The authors thank Clotilde 
Berger-Pompili and Mathilde Leygnac, directors of the EHPAD du Pays de Menat, for their kind help and authorizations to collect fossil insects in a small but rich outcrop near the village of Menat (Puy-de-Dôme, France). The study was supported by the Russian Foundation for Basic Research (grant 18-04-00243-A for both authors and 19-04-00465-a for A. G. Kirejtshuk), by the state research projects No. AAAA-A17-117081640018-5 (M. V. Nabozhenko) and No. AAAA-A19-119020690101-6 (A. G. Kirejtshuk), by the programme of the Presidium of the Russian Academy of Sciences "Evolution of the organic world. Significance and influence of planetary processes".

\section{REFERENCES}

Alekseev, V. I. \& Nabozhenko, M. (2015): A new fossil tenebrionid beetle of the tribe Palorini (Coleoptera: Tenebrionidae) from Eocene Baltic amber. - The Coleopterists Bulletin 69: 127-130. http://dx.doi.org/10.1649/0010-065X-69.mo4.127

Alekseev, V. I. \& Nabozhenko, M. V. (2017): Palorus platycotyloides sp. n., the second fossil representative of the tribe Palorini (Coleoptera: Tenebrionidae) from Baltic amber. Acta Zoologica Bulgarica 69: 167-170.

Ando, K. \& Schawaller, W. (2006): Two new species of the genus Spiloscapha (Coleoptera, Tenebrionidae) from Laos and Vietnam. - Japanese Journal of Systematic Entomology 12: 127-131.

Bousquet, Y., Thomas, D. B., Bouchard, P., Smith, A. D., Aalbu, R. L., Johnston, M. A. \& Steiner, W. E. JR. (2018): Catalogue of Tenebrionidae (Coleoptera) of North America. - ZooKeys 728: 1-455. https://doi.org/10.3897/zookeys.728.20602

Chang, H. L., Nabozhenko, M., Pu, H. Y., Xu, L., JiA, S. H. \& Li, T. R. (2016): First record of fossil comb-clawed beetles of the tribe Cteniopodini (Insecta: Coleoptera: Tenebrionidae) from the Jehol Biota (Yixian Formation of China), Lower Cretaceous. - Cretaceous Research 57: 289-293. http://dx.doi.org/10.1016/j.cretres.2015.09.001

Doyen, J. T., Matthews, E. G. \& Lawrence, J. F. (1990): Classification and annotated checklist of the Australian genera of Tenebrionidae (Coleoptera). - Invertebrate Taxonomy 3 (1989): 229-260. https://doi.org/10.1071/IT9890229

Doyen, J. T. \& Poinar, G. O. (1994): Tenebrionidae from Dominican amber (Coleoptera). Entomologica Scandinavica 25: 27-51. https://doi.org/10.1163/187631294X00027

Grimm, R. (2010): New and little known species of Tenebrionidae (Coleoptera) from Borneo. - Stuttgarter Beiträge zur Naturkunde A, Neue Serie 3: 257-267.

Hörnschemeyer, T. (1994): Ein fossiler Tenebrionide Ceropria? messelense n. sp. (Coleoptera: Tenebrionidae: Diaperinae) aus dem Mitteleozän der Grube Messel bei Darmstadt. - Courier Forschungsinstitut Senckenberg 170: 75-83.

Kedves, M. \& Russel, D. E. (1982): Palynology of the Thanetian layers of Menat. The Geology of the Menat Basin, France. - Palaeontographica B 182: 87-150.

Kaszab, Z. \& Schawaller, W. (1984): Eine neue Schwarzkäfer-Gattung und -Art aus Dominikanischem Bernstein (Coleoptera, Tenebrionidae). - Stuttgarter Beiträge zur Naturkunde Serie B (Geologie und Paläontologie) 109: 1-6.

Kirejtshuk, A. G., Merkl, O. \& Kernegger, F. (2008): A new species of the genus Pentaphyllus Dejean, 1821 (Coleoptera, Tenebrionidae, Diaperinae) from the Baltic amber and checklist of the fossil Tenebrionidae. - Zoosystematica Rossica 17: 131-137.

Kirejtshuk, A. G., Nabozhenкo, M. V. \& NeL, A. (2010): New genus and species of the tribe Opatrini (Coleoptera, Tenebrionidae, Tenebrioninae) from the Lowermost Eocene 
amber of Paris Basin. - Proceedings of the Zoological Institute of the Russian Academy of Science 314: 191-196.

Kirejtshuk, A. G., Nabozhenko, M. V. \& Nel, A. (2011): First Mesozoic representative of the subfamily Tenebrioninae (Coleoptera, Tenebrionidae) from the Lower Cretaceous of Yixian (China, Liaoning). - Entomologicheskoe Obozrenie 90: 548-552. [in Russian] [English translation (2012): Entomological Review 92: 97-100.] https://doi.org/10.1134/ S0013873812010101

Kirejtshuk, A. G. \& Nel, A. (2018): Nitidulidae (Coleoptera) from the Paleocene of Menat (France). - Zootaxa 4402: 1-41. https://doi.org/10.11646/zootaxa.4402.1.1

Legalov, A. A., Kirejtshuk, A. G. \& Nel, A. (2017): New and little known weevils (Coleoptera: Curculionoidea) from the Paleocene of Menat (France). - Comptes Rendus Palevol 16: 248-256. http://dx.doi.org/10.1016/j.crpv.2016.10.007

Legalov, A. A., Kirejtshuk, A. G. \& Nel, A. (2019): The oldest genus of the subfamily Sagrinae (Coleoptera: Chrysomelidae) from the Paleocene of Menat (France). - Comptes Rendus Palevol 18: 178-185. http://dx.doi.org/10.1134/S0013873818070084

Matthews, E. G. \& Bouchard, P. (2008): Tenebrionid beetles of Australia: descriptions of tribes, keys to genera, catalogue of species. - Australian Biological Resources Study, Canberra. $410 \mathrm{pp}$.

Mayr, G., Hervet, S. \& Buffetaut, E. (2019): On the diverse and widely ignored Paleocene avifauna of Menat (Puy-de-Dôme, France): new taxonomic records and unusual soft tissue preservation. - Geological Magazine 156: 572-584. https://doi.org/10.1017/ S0016756818000080

Medvedev, G. S. (1977): Taxonomic significance of antennal sensilla of darkling beetles (Coleoptera, Tenebrionidae). Pp. 61-86. In: Medvedev, G. S. (ed.): Trudy vsesoyuznogo entomologisheskogo obshchestva. Vol. 58. Morphological bases of the systematics of insects. Nauka, Leningrad. [in Russian]

Medvedev, L. N. (1969): New Mesozoic beetles (Cucujoidea) of Asia. - Paleontologicheskii Zhurnal 1: 119-125. [in Russian]

Nabozhenko, M., Bukejs, A. \& Telnov, D. (2019a): Gonialaenini, a new tribe of Lagriinae (Coleoptera: Tenebrionidae) from Eocene Baltic Amber. - Zootaxa 4565: 253-260. https://doi.org/10.11646/zootaxa.4565.2.9

Nabozhenko, M. V. \& Chigray, I. A. (2018): New and little known species of Alleculini (Coleoptera: Tenebrionidae: Alleculinae): extinct from Eocene Baltic amber and extant from Lebanon. - Caucasian Entomological Bulletin 14: 171-176. https://doi. org/10.23885/181433262018142-171176

Nabozhenko, M. V. \& Kirejtshuk, A. G. (2014): Cryptohelops menaticus - a new genus and species of the tribe Helopini (Coleoptera: Tenebrionidae) from the Palaeocene of Menat (France). - Comptes Rendus Palevol 13: 65-71. http://dx.doi.org/10.1016/j. crpv.2013.09.005

Nabozhenko, M. V. \& Kirejtshuk, A. G. (2017): The oldest opatrine terrestrial darkling beetle (Coleoptera: Tenebrionidae: Tenebrioninae) from the Paleocene of Menat (France). - Paläontologische Zeitschrift 91: 307-313. https://doi.org/10.1007/s12542-017-0368-2

Nabozhenko, M. V., Kirejtshuk, A. \& Merke, O. (2016): Yantaroxenos colydioides gen. and sp. n. (Tenebrionidae: Lagriinae) from Baltic Amber. - Annales Zoologici 66: 563-566. https://doi.org/10.3161/00034541ANZ2016.66.4.008

Nabozhenko, M. V., Chang, H., XU, L, Pu, H. \& JiA, S. (2015): A new species and a new genus of comb-clawed beetles (Coleoptera: Tenebrionidae: Alleculinae) from Lower 
Cretaceous of Yixian (China, Laoning). - Paleontological Journal 49: 1420-1423. https:// doi.org/10.1134/S0031030115130079

Nabozhenko, M., Chigray, I. \& Bukejs, A. (2019b): Taxonomic notes on the Eocene Helopini, and a review of the genus Isomira Mulsant, 1856 from Baltic amber (Coleoptera: Tenebrionidae). - Insect Systematics and Evolution. 15 pp. https://doi. org $/ 10.1163 / 1876312 X-00002302$

Nabozhenko, M. V., Perkovsky, E. E. \& Chernei, L. S. (2016): A new species of the genus Nalassus Mulsant (Coleoptera: Tenebrionidae: Helopini) from the Baltic amber. Paleontological Journal 50: 947-952. https://doi.org/10.1134/S0031030116090082

NeL, A. (2008): The oldest bee fly in the French Paleocene (Diptera: Bombyliidae). - Comptes Rendus Palevol 7: 401-405. https://doi.org/10.1016/j.crpv.2008.08.001

Nel, A. \& Auvray, F. (2006): The oldest Vespinae from the Paleocene of Menat (France) (Hymenoptera: Vespidae). - Zootaxa 1344: 59-62. https://doi.org/10.11646/zootaxa.1344.1.5

Pic, M. (1926): Entomologische Ergebnisse der Schwedischen Kamtchatka-Expedition 1920-1922. 7. Coleoptera. - Arkiv för Zoologi 18B: 1-5.

Piton, L. (1940) Paléontologie du gisement éocène de Menat (Puy-de-Dôme), flore et faune. - Mémoire de la Société d'Histoire Naturelle d'Auvergne, Clermont-Ferrand 1: 1-303.

Schawaller, W. (1995): The genus Basanus Lacordaire (Coleoptera. Tenebrionidae) in continental south-eastern Asia. - Acta Zoologica Academiae Scientiarum Hungaricae 41: 327-334.

Schawaller, W. (1997): The genus Spiloscapha Bates (Coleoptera: Tenebrionidae), with descriptions of new species from the Oriental and Papuan regions. - Stuttgarter Beiträge zur Naturkunde, Serie A (Biologie) 566: 1-15.

Schawaller, W. (2003): Two new species of Scaphidema Redtenbacher (Coleoptera: Tenebrionidae) from Nepal and China. - Stuttgarter Beiträge zur Naturkunde Serie A (Biologie) 653: 1-7.

Schawaller, W. (2004): New species and records of the genus Spiloscapha Bates (Coleoptera: Tenebrionidae) from the Oriental and Papuan Regions. - Stuttgarter Beiträge zur Naturkunde Serie A (Biologie) 661: 1-10.

Schawaller, W. (2006): New species and records of the genus Basanus Lacordaire (Insecta: Coleoptera: Tenebrionidae). - Revue suisse de Zoologie 113: 239-246. https://doi. org/10.5962/bhl.part.80347

Schawaller, W. (2008): Three new species of Scaphidema Redtenbacher (Coleoptera: Tenebrionidae) from China. - Stuttgarter Beiträge zur Naturkunde Serie A (Biologie) 1: 381-385.

SchawAlleR, W. (2011): New species and records of the genus Basanus Lacordaire (Coleoptera: Tenebrionidae), part 3. - Special Bulletin of the Japanese Society of Scarabaeoidology (Masumushi) 1: 285-292.

Schawaller, W. (2012): New species and records of the genus Spiloscapha Bates (Coleoptera: Tenebrionidae) from the Oriental and Papuan Regions (part 2). - Zootaxa 3336: 62-68. https://doi.org/10.11646/zootaxa.3336.1.4

Schawaller, W. (2016): Laoscapha phoupanense gen. et sp.nov. (Coleoptera: Tenebrionidae: Diaperinae) from Laos. - Entomologica Basiliensia et collectionis Frey 35: 439-442.

SchawAller, W. \& ANdo, K. (2006): New species and records of the genus Basanus Lacordaire (Coleoptera, Tenebrionidae), part 2. - Japanese Journal of systematic Entomology 12: 215-223.

Soldati, F. \& Nabozhenko, M. (2017): Asida groehni sp. nov., the first and the oldest fossil representative of the subfamily Pimeliinae from Eocene Baltic amber (Coleoptera: 
Tenebrionidae: Asidini). - Annales Zoologici 67: 555-559. https://doi.org/10.3161/0003 4541ANZ2017.67.3.003

Telnov, D., Bukejs, A. \& Merkl, O. (2019): Description of a new fossil Statira Lepeletier et Audinet-Serville, 1828 (Coleoptera: Tenebrionidae: Lagriinae) from Baltic amber of the Sambian Peninsula. - Zootaxa 4683: 508-514. https://doi.org/10.11646/ zootaxa.4683.4.2

Vitali, F. (2007): A new species of Corticeus Piller \& Mitterpacher, 1783 from Dominican amber (Coleoptera Tenebrionidae). - Entomapeiron (P.S.) 2: 1-6.

Vitali, F. (2008): A new species of Tyrtaeus Champion, 1913 from Dominican amber (Coleoptera Tenebrionidae). - Entomapeiron (P.S.) 3: 11-16.

Wappler, T., Currano, E. D., Wilf, P., Rust J. \& Labandeira, C. C. (2009): No post-Cretaceous ecosystem depression in European forests? Rich insectfeeding damage on diverse Middle Palaeocene plants, Menat, France. - Proceedings of the Royal Society $B$ 276: 4271-4277. https://doi.org/10.1098/rspb.2009.1255

Watт, J. C. (1974): A revised subfamily classification of Tenebrionidae (Coleoptera). New Zealand Journal of Zoology 1: 381-452. https://doi.org/10.1080/03014223.1974.9517846

Wiскнам, H. F. (1912): The Princeton collection of fossil beetles from Florissant. - Annals of the Entomological Society of America 6: 359-366. https://doi.org/10.1093/aesa/6.3.359

Wiскнам, H. F. (1913): Fossil Coleoptera from Florissant in the United States National Museum. - Proceedings of the United States National Museum 45: 283-303. https://doi. org/10.5479/si.00963801.45-1982.283

Received July 29, 2019, accepted October 23, 2019, published March 6, 2020 
